\title{
閉鎖循環式気管内麻酔による舌癌根治 手術に就て
}

\section{Radical operation of tongue cancer by closed circuit endotracheal anesthesia}

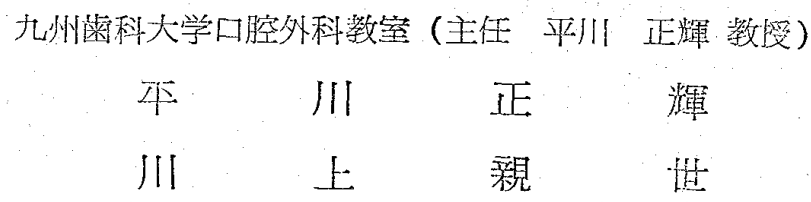

\section{緒訔}

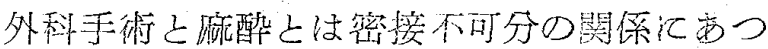

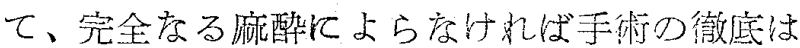
期し難い、とい5も過言ではない。数年来外科 各分野江於计る手術の発洼は誠江目ざなしいる のがあるが、このような外科手術の進步江詨し

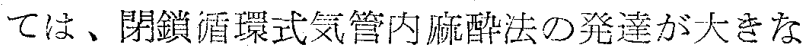
役制尼演じている事は續々述べる京でも声るま h。

然し乍ら安全伅して多くの長所を具えを本浩 女、乙れを影外科領域江些て応用しょうとする 場合には简幾多の問題が残されている事も見の

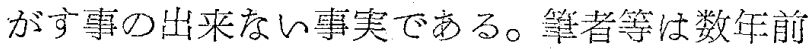

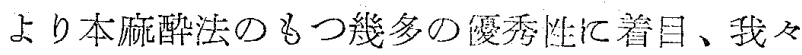
の専門とする顎外科手術化灾用しをんとの合願

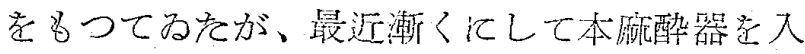
手し得をので、色々の国奞存る闊題党復しつ

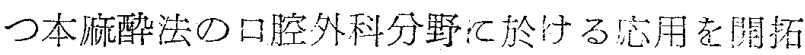
しつつある。

かかる折から相次いで舌癌つ 2 测汇遶遇、本

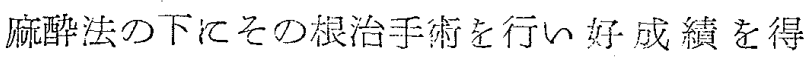

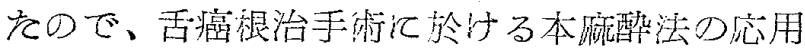
と、その手術々式䔽する我々の見解を述べて 諸豎の御参考䝺する次第でする。

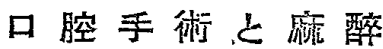

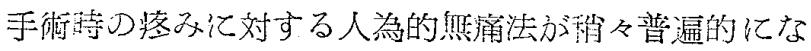

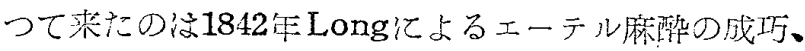

1844年 H. Wells の笑気附醉による拔崡の実施、1847

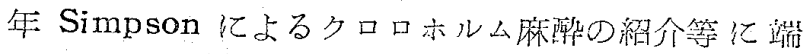
を発している。各種口腔外科的手術も、ほぼその術式が 確立された頭初に於ては、主としてクロロホルム或は

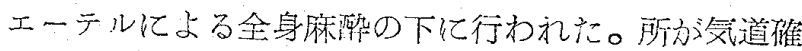
保の出来難い当時の原始的吸入麻唒々よつて口腔領域

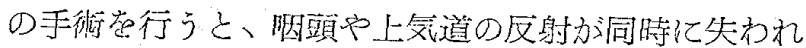
るので、口腔に充瀮した血洃や分泌物を気道内に吸引 し、その為䇪息、或は術後级引性昁炎范併発、そ㣗 上る予後不良例方泏る事定避け得なか力た。一う1900 年に到ると Einhorn（1905年）により極好て宽全域 の広い局所麻酰郕で岁るプロカインが紹介され、更に そ礼つづいて Härtel, Braun, Offerhaus, Pichler 等によつて三文神経翰及び半月神経節への頭琵戍或は

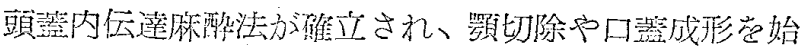

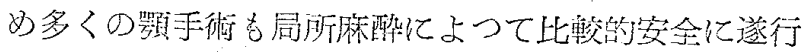
されるようになり、窒息や吸引性脚炎の色除吉除か

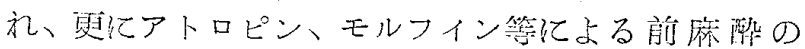

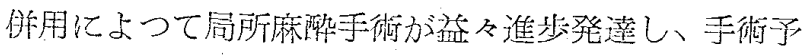
後の向上に重大な役割赏演じて来た。それで今世紀の

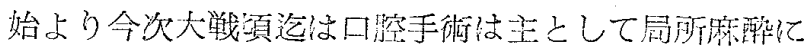

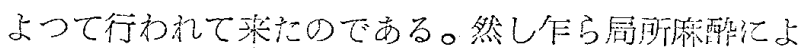

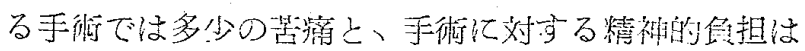

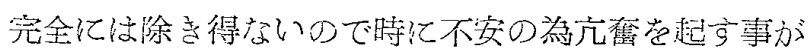
あり、この事は手術に刘する好条件と位言えない。特 に舌切除や、舌の後退を起し易い下碩碩部の切除等に

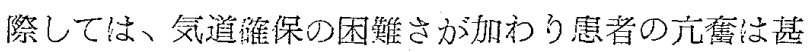
しく、手術が長時間任亘る場合も亦呞所麻醉手術では

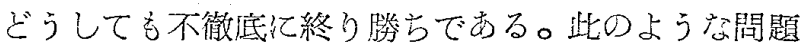


と其に更に人道的兌地からも、より安全な全く苦悩を

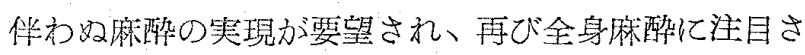
れるようになつたのは当然の成行きであつて、戦後急 速億及発達しつつある閉鎖循環式気營内麻酛法は一 応しの目的纪近い磨醉法と見做す事が出来る。

本法は口腔又は鼻腔を経て気管内にカテーテル苞插

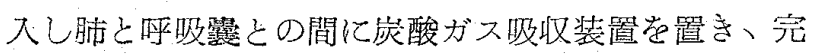

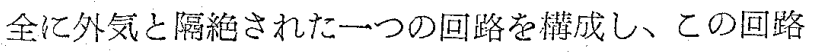

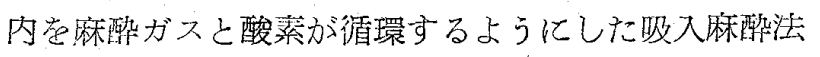
であつて、麻醉戍としてはエーテル、サィクロプロペ イン、笑気等力酸素と一所得いられる。（第1図及 び第 2 図渗照)

本法の利点としては(1)気道の隺保、これは舌の泿下 や、日腔陌頭部に血液其他の眝溜し易い広沉な上下顎 切除や、舌癌手術にあたつて特に街者の切望する間題 であるが、気管内堔酸によつて始めてての目的は達成 され、気管内に貯溜した分䎵物も気管カテーテルを通 じて眨引除去する夏が出来る。(2)酸素は回路内に送る 事によつて充分に与元られ、又必要に応じては調節呼

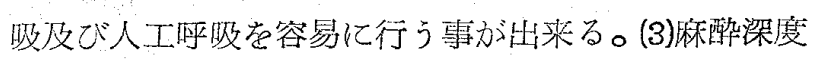
の一定維持が容易である。(4)死空は插管しない場合に 比し小さくすることが出来る。胣つて炭酸ガス蓄積が

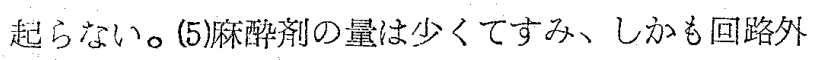

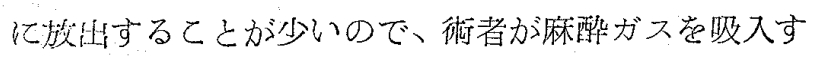
る心配もなく、また爆発の危険も少ない。

以上口腔手術と麻醉発展過程の関係について述べた が、てれからも籍光るように麻醉は始め知覚の1時的

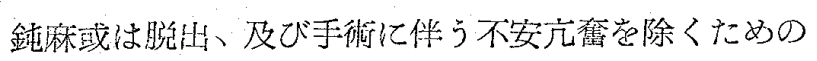
意識消失を目的として発足したのであつて、彷来の概 念としては、身体各系付対する影響を出来るだけ少く し、しかも述のような目的を達成するの方理想とさ 礼て来た。即ち麻醉は一種の病癿生理であるから、身 体各系の状態も亦所謂正常状態から甚しく逸脱しない ととがのぞましいとされていた。それが杯酰及び外科 学の進装と共に㴬次変化し、手術の種類によつては筋

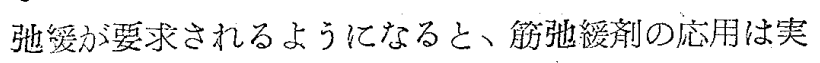

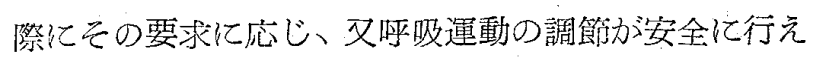
るようになつたのである。更に又フランスに於て自律 神経に対する調節作用をもつた Phenothiazine 系誘 導体のChlorpromazine が合成され、Laborit 一派 による人工冬服或は強化麻醉の理論力溌表されるに及 んで麻醉の概念にも一大恋革就りつつある。

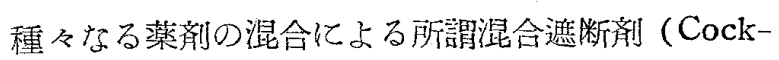
tail litique)の適量を投与して自律神経の作用を極度
に抑制或は遮断すると諸種代謝は最低となり、組織の 酸美消費量㐘檄》て低下し、通常必要量以下の酸素供 給しか行われない非常事態に対しても組織住生活を続 ける事が出来る。諸種有害反射も低下乃至は消失し、 意識及び演覚感受性も併せて低下するので麻醉剤の便

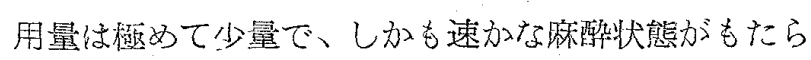
される。以上的即ち Laborit 等の陧える強化腹醉の 理論である。更住自律神経系を楽郕で遮断し、患者を

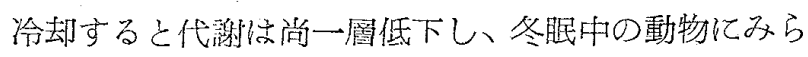
れるような緩除な生活現爱となり、外来刺戥にも反応 しなくなる。此の状態は人工冬眠であつて、生体のか 悋る状態堂 Laborit 等は『弛㣪せる生活体 vie ralentie』と四び、冬眠動物に見られる状刽とよく似て いる。冬跟状態でなけ扎ば当然死に到る寒泠の侵留に 対して、冬服下の動物はよく生命を維持出来ると同様 に、冬跟下の生体は非冬眠生体の酎光得ないような手

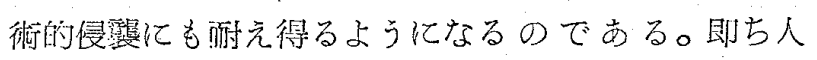
工冬服に於ては正常状態と全く異つた状態の下に生命 維持し手術とその影響の柽減觉図るのであるから、 麻醉の概念も従来のそれとはかなり這ざかつたものと なりつつある。

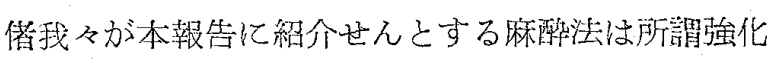

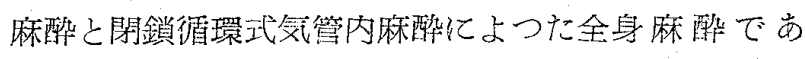
る。

\section{自 家 経 験 例}

[症例 I ]患者：下○虎○30才 $\hat{\text { o }}$

主訴：左舌根部舌緣、舌下粘膜部、翼状下顎嵧壁部及 び㳄口䈍の一部に宣る癌性潰癔形成。

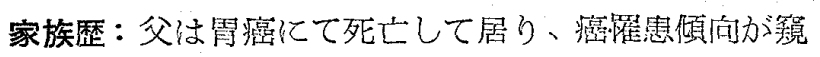
われる。

現病歷：息者は昭和31年 1 月頃より左舌後緑より舌下 粘膜部に亘り供和感を自覚、3月に到ると提食時に

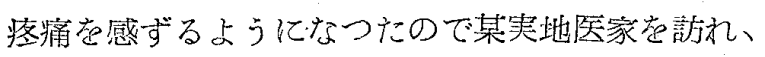
対症療法を受けた。所方同症状は僅汃乍方も增悪の 做向学示し、時々同部より出血を見るようになつた ので 8 月上旬には一度当科党訪れている。当時㟝察 の結果癌性溃湯が想像されたので武片を採取、本学 病理学教室に組織学的検查起低頼した所、癌前变化 なる解答を得たので即時入院手術をすするたが、当 時㭧者注学意を決し難く、暫く来院しなくなつた。 此の間病変注徐々に増瑟をつつけけ11月上旬には某 医の紹介によつて再度当科壳訪えた。

現症：体格、栄養状態共に中等度。胸部腹部には著変 
を見ない。体重 $45 \mathrm{~kg}$ 、血液検査所見としては赤血 球 410 万、白血球数 6.800 、血色菜量 $80 \%$ 、血洗値 I 時間 $1.5 \mathrm{~mm} 、 2$ 時間 $6 \mathrm{~mm}$.

ワッャルマン、村田、カーン反応共に陰性。M.C.

R. 陰性。

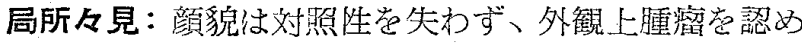

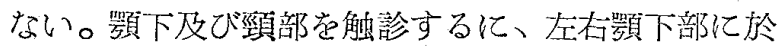
て小指尖大の可動生淋巴節症数触的るのみにて他 に著変を見ない。開口を命ずるに開口度 2.5 横指僅 加開口障碍㕝訴える。左側舌後縁より下面党中心 とし、同部舌下粘膜及び来状被壁に沿つて前方へ拡 大しつつある潰瘍が認められる。病変伱後方に於て

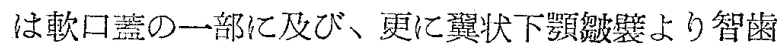

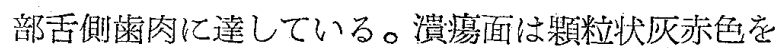

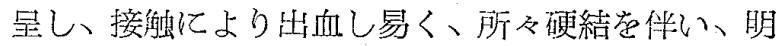
かに癌狌潰瘍の所見量し、同側舌下腺部に沿つて は硬結を触える（第 3 図渗照）。患側下顎の大、小 曰菌恬側へ傾斜し、長特間任亘る舌への機械的刺 戟が想像された。

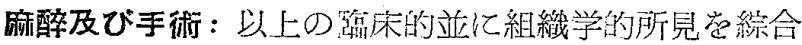
乙舌癌根治手術壳行う事堂決定、昭和 31 年11月27日 乙れ䒠推した。手術前夜就寝時 Pacatal $100 \mathrm{mg}$ + Ravona 100mg 起経口投与、当日術前 2 時間记 Pacatal 50mg 筋终内注射し、更飞術前 1 時間に Pacatal $50 \mathrm{mg}+$ Opystan $70 \mathrm{mg}$ の筋肉内注射

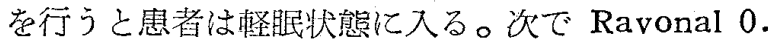
3gr の静脈注射によつて麻醉唀導、先づマスクに てェーテルの闒鎖循環式吸入麻酰学開始、約40分後 に声門の完全㷁開が認められたので気管内チューブ

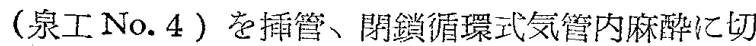
換えて手術を開始した。（表工参照）尚術中の出血 壘減少学は汃る意味に於て塩酸エピレナそン加 $1 \%$

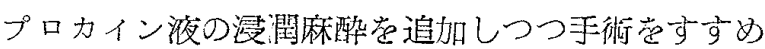
た。皮切は顎下部より胸鎖乳頭筋部に達する顎下部 马状切開にて大り、先つ顎下喠液腺を摘出、次で顴

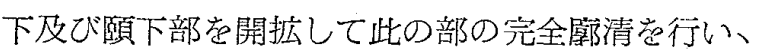
更に上頸部淋巴節を可及的摘出する。次で下口唇中 央より願下に㫤る綎切開を追加し前切開創に連続、 顿顿組織觉下顎骨より䟝離翻転し、下顎骨を露出、 下䫇切断刀をかけて下顎体部を切断する。つづいて 切断部より後方の下顎片を外側に疄転、手術野を広

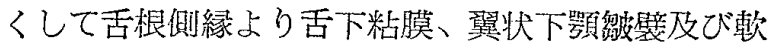

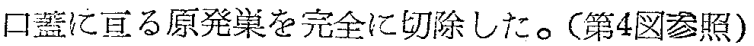
次で全創面の完全止血を図つた後下㖽片を整復し、
銀線結紮を行つた後 2 梊に小ドレーンを残して軟 組織を檤合し手術を終る。経過岄大凡㮌調であつて 術後29日にて手術創は一店治痖退院した。治瘾後に 於て舌は手術側下颚の舌側及び口底軟組織と痖着す るので积々短縮するが、機能的には談話時に㮐々不 自然さ荧感ずる程度である。術後 4 ケ月を経過した 現在胴瘍の再発を見ない。

\section{症例 II 患者：池○博○ 36才合}

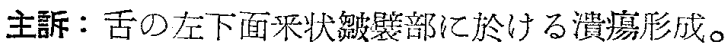

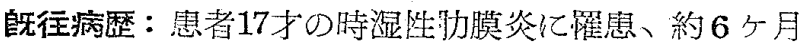
の療蒦赏行つた事方がる。

家族歴並に生活歷：思者叔父の 1 名は胃癌にて死亡し ている。患者はアルコール性领料に数しむ機会多く 又煙草は20才頃より喍む。

現病歴：原々著しく舌倒に傾斜していたが数年前より

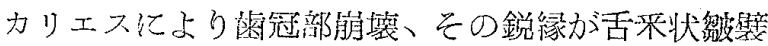

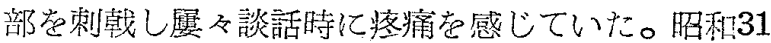

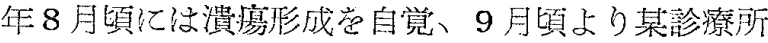
にて刘症療法至受け、10月に估著しく舌側无傾斜し た原の技去を受けている。拔崡はプロカインによる

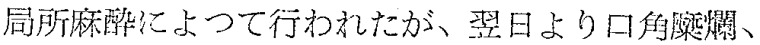
口唇浮藏、口腔粘膜のカータル症蚛等荧起し、数日 後に消退したという。その後疼蒋柱柽快したが、左

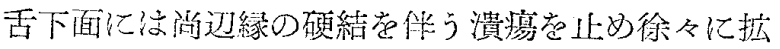

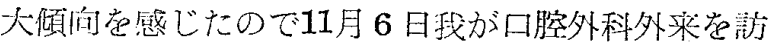
れた。

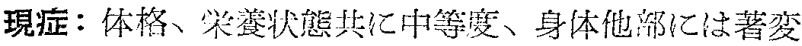

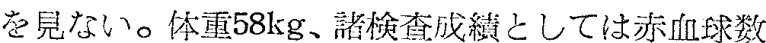
523 万、白血球数 6500 、血色素量 $100 \%$ 、血压(唒位) 80 - 126 mm. Hg.。 白血球百分率 B 0.5\%、E 2.5 $\%$, St $3.0 \%$, S $49.5 \%$ L $38.5 \% 、$ M $6.0 \%$ 。

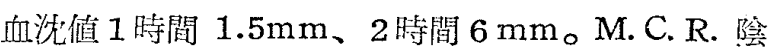
性。ワッセルマン、村田、カーン反応共に答性。 尿、楼、蛋白其嗱性。

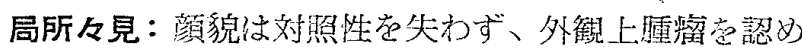

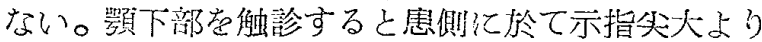
小指尖大に宣る数っの泆巴節腫大が連鎖状にふれ る。開口管命ずるに牙関緊念はない。舌前後径の中

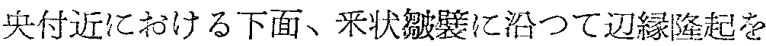
伴う珢指頭大の潰場がある。潰㾤面は灰黄赤色、稍々 頻粒状屾古があり、接能により易出血性である。そ の周团より舌下輁液腺部にかけてはかなりの磦結を

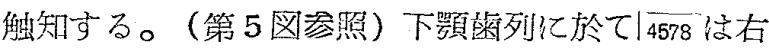
傊に比し舌側傾斜著しく、長年に㫜る舌えの機根的 
刺戟が想像されだ。

処置並に経過：初彭以来対症療法觉行いつつ維察觉つ

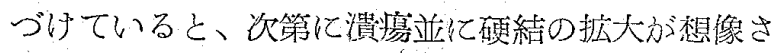
虬たので11月26日入院觉許し、27日には $2 \%$ ロ イン局䏫の下に漬序の1部より試片を採取、組織検 查を依頋した。所訪試片採取の装日より口角及び口

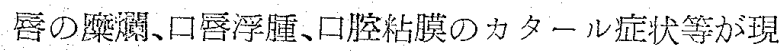

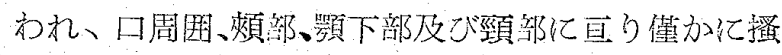

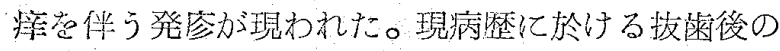
症状と作せてプロカインに対する特㗨質が想像され たので、2\%プロカインによる皮内反応を行つた所、 即時反灾としては著変点見なかつたが18㭙閐後には 生理的食篮水対照 カイン注射部は発告 $45 \times 40 \mathrm{~mm}$ 觉示し、プロカイン

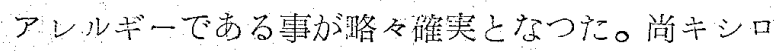
カインによるテストで性陽性を示さず、100u/ $\mathrm{cm}^{3}$

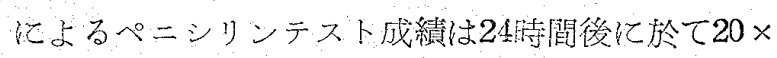
$25 \mathrm{~cm}$ で器陽生を赤した。

試片の組織学䄪検查の結果经前例同椂癌前变化な る解答を得たが、諸般の姃状定的世判断し舌癌根治

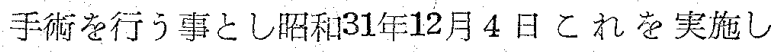

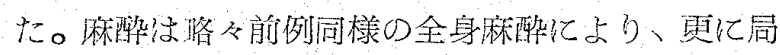

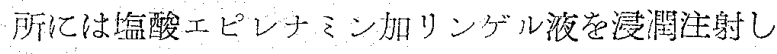
つつ、略々前例同样の街式にて手術定与すめ、出血

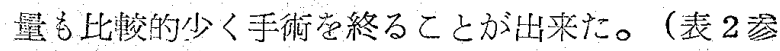

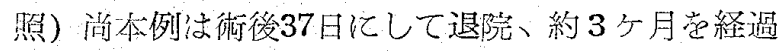

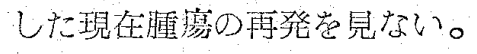

\section{考察}

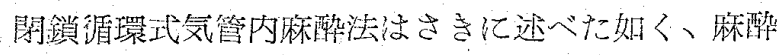
の般的要求にそう多くの基本的条件真えていて、 舌癌根治手術に於ても此の長所は䢙感なく発揮され る。特て気道が完全て確保されているので街中雨吸障 碍の不安は全くなく、術者は病单除去に完全学期する

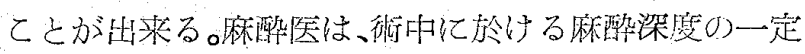

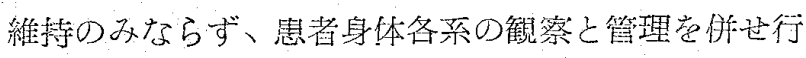
い、出血、体㴕の豆失、心機能、循環系並に血王等の多動

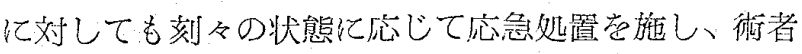

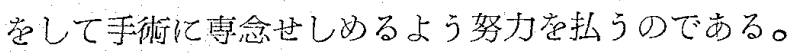

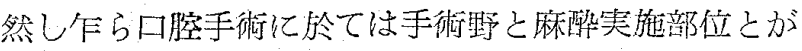
同一部位となるので、麻酤奏施面に於ては胸腹部手術 の際と異り 2 - 30困雉な問題が伴つて来る。斯ちを

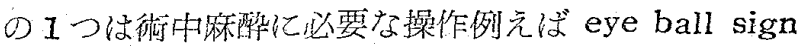

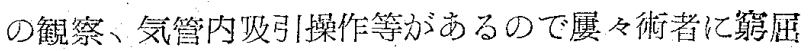

な思いをさ也るととであるが、此の問題は術者と麻酔 医の相互理解と協力によつて何と加解決できるので、 あまり大きな障㥂とはならなかつだ。

第 2 の問題は気管内テニーブに接続する回路の固定 に一考要要するととである。此の問題に対して著者等 は特殊の国定架台学萦案してれ觉用いているが、此の 架台は支柱の商さ及び長さ总自由に調節出来るよう亿

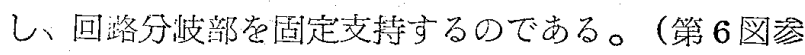
照)

第 3 の問題は手術による下顎の轻移を防止する為滑 面板等の颚間副木や、各種歯牙副木を施す場合が多 く、しかもてれらは大低術前から装看しなければなら ないので、気管内テューブの插管時、或は㩕管後の維 持に多少の困嚾煘ずるととがある。我々の[症例 I] 下○例に於てはマルチン滑面板副木を装者していた が、摴管にあたつて大きな障得とはならなかつだ。 ユーブ固走得しては現在の所、稍々長めの晈マセ木 を作り、とれを刘㒋の画列間に固定し、しれにチーブ

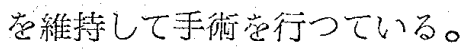

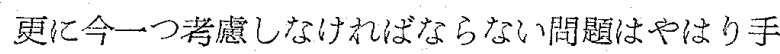
術野との関係上、気残内子ユーブや陵マセ木、回路接

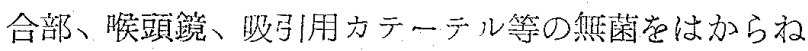
ばならないととである。我々は現在の所、てれらは紫 外線殺菌燈によつて堿菌し、しの間題の解決老々加つ ている。

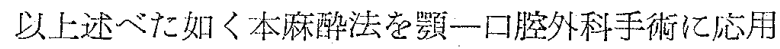

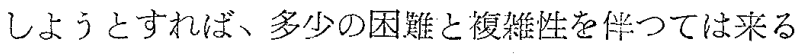

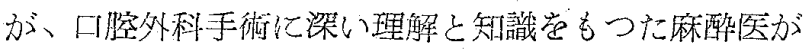
これにたづさわればてれらの難点を克伏して本睏䤏法 の長所を遺感なく発濹するととが出来る。

次に舌癌の手術にあたつては原発栄の完全除去、顎 下及び碩下淋巴節の完全廓清を行うこと、必要に応じ

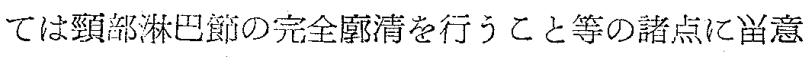

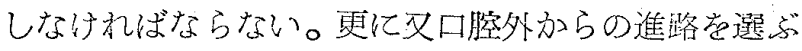

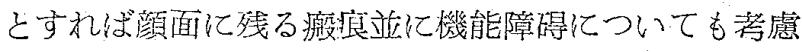

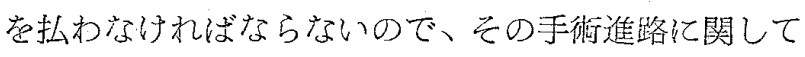
は往来諸家によつて色々の術式が考案されている。今 それらの主なるもの等げしれ荐察してみると：

(1)経口的手術Die Operation vom Munde aus.

口腔より舌癌病棠を切除する術式であつて、舌赶部 に近い初期のものに適する㫱式とされているが、著 者等の経験によれば原発巢の胢除だけならば中恬 縁部志でのものは勿論、方なり後方舌緣附近のもの 志でも経口的切除するとと加出来る。事実篗者等 
は本法によつて切除後、2 次的に顎下、碩下淋巴節

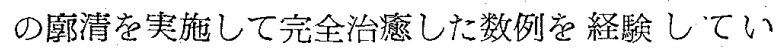
る。然し作ら舌根に及ぶものや、初期堂過ぎた舌癌 に対しては手術が糸底しないので、このような例に 対しては本法が適應でないととは述べるまでもな い。

(2)顂新横切開による舌切除、Die Keilexzision mit Wangen schnitt.

Jäger 術式として成書に記載され、口角より賽を㕮 筋前縁迄横切し、舌切除学行う術式（第 7 図a）で あるが、原発栄切除偣対する手術野が稍々広くなる

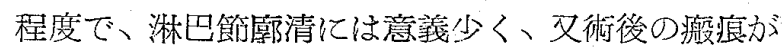
目立つのであまり推称すべき方法ではない。

(3)下顎の整間的鋸断による舌切除、Die Zungenresektion nach temporärer Unterkieferdurchtrennung. Der transmandibulare Weg. 乙札は久 次の 2 つの進路がある。

(a)下顎体部范鋸断して進む方法、Die seitliche Durchtrennung des Unterkiefers nach $\mathrm{v} . \mathrm{La}^{-}$ ngenbeck. (第 7 図 b) Langenbeck (1875) 或は Langenbeck-Bergmann 法とよばれる進路であつ

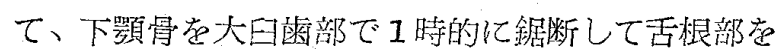
広く露出、原発栄の徽底的切除と、䪽下及び頸部の 淋巴暗清が同特に行えるので最近迄各方面でよく用 いられて来た術式である。然し乍ら我々口腔外科亦 門医の立場より本法を観察すると Langenbeck 或 は Bergmann 法にしても皮切が角に始つて下頓 部を通り、顎下及び上頸部に達しているので、街後

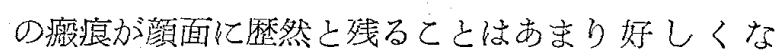
い。更に後藤もその著書隹いて震及しているょう に、この皮切より入つて下顎鋸断したとしても、 舌根部或浽顎下部開放の為得られる手術野はさほ ど広いものではない。私は最近根本的に改良堂加え た経下顎的舌㴦根治手術々式在考案実施して比較的

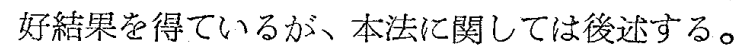

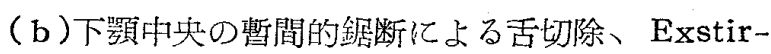
pation der Zunge mit medianer Durchtrennung des Unterkiefers. Sedillot (1844) 或はKocher 術式として知ら礼ている。(第8図)下口唇 中央より臨下部に亘り縦切、下顎中央鋸断し舌切 除尼行う術式であるが、舌後方の術野は充分でな く、又顎下淋巴節以外の淋巴皠清も徹底しない久点 がある。

(4)顎下或は願下より進む方法、Der submandibula- re Weg. Cloquet は1827 仠に早くも本進路による 舌骨上部よりの舌癌手術觉行つて和り、Regnoli住 1838年願下T型切開による手術々式を発表してい る。Birllothも亦下顎縁俉うU字型切開による 舌癌切除觉行つている。更側方颚下部より進吉方 法としては Kocher（第7図c）、或は Bergmann 等の術式の1つとして従来の成書仙記載されて いるが、てれらの原法では舌根部の町除にあたつて 尚手術野が充分とはい光ない。

然るに最近後藤（1954）は舌根部露出のために は、口腔底解放に引つづき舌骨上緑老目標に呐頭芭 開放して行けば下顎鋸断の必要はなくなることを着 目、本進路による側舌骨上口腔咽頭切開術（Bucco-pharyngotomia-suprahyoidea lateralis) 名舌骨上舌切除琎 (Suprahyoideale Zungenresektion）なる術式を完成した。（第9図）此の方 法は胸鎖乳頭筋に沿う切開之、願部より此の切開に

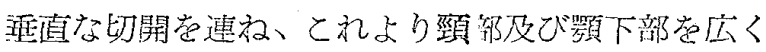
露出、完全頸部廓清、顎下及び願下の部清につー゙き

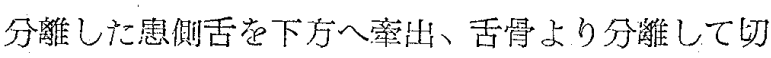
除するのである。

後藤の手術は耳鼻科医の立場より確立されたものので あつて、頸部の完全崕清に引つづき舌骨を基準に手術 を進め、咽頭口腔の開放任应い手術野が得られるのが 特徴であつて、様式化された】新手衔法としては全く

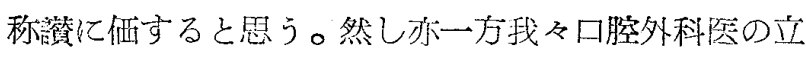
場より兒ると、舌癌と雖も舌と口墕底軟組織に止つて いるとは限らず、我々の兒るものの内には更に翼状下

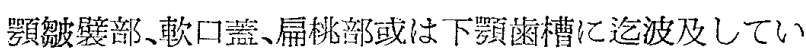

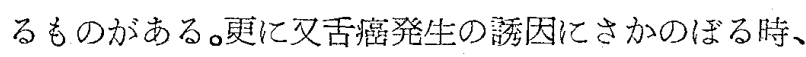

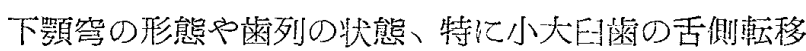
や傾斜、第 3 大曰歯の方向異常等肪舌縁或恬舌下面の機 椷的刺戟源となつているととが想像される例も多い。 此のような列には舌切除に終止するととなく、雨列や 顎急改善の目的のために下颚への手術が必要になるこ

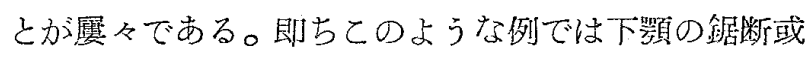
は時にそのI部の同時切除方必要になるのはどうして も止む得ないてとである。このような点を考慮し需

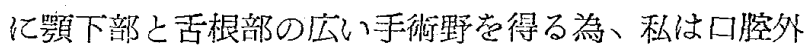
科的立場より下唄側方鋸断法にぞくする独特の手術法

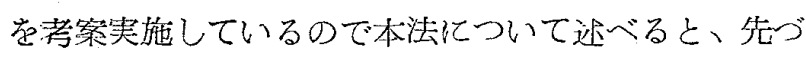
下方は舌骨の高さに及ぶ顎下部忿状切開で手術を始 め、脑鎖乳頭筋前縁より舌骨上の所謂顎下三的 (submandibulare Dreiecke) 童充分露出する。次は顎下三 


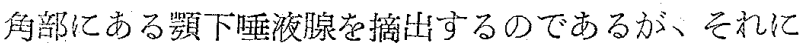
は先づ下部より上方に府つて結合織被膜より分䌖して 行き後方を注意し乍ら得離すると、一部腺内点貫く颜

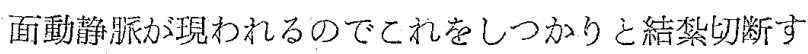
る。ての血管の処置が済文ば崜液腺及びその周团占り の出血は急に少くなるので以後の手術は容易になる。 顎下腺摘出につづいて顎下及び碩下淋巴節を I Block として摘出する。更に上钼部淋巴節迄はこの切開鴒よ り摘出することが出来る。次に下口唇中去より畽下に

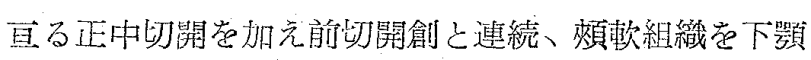
骨より永離翻転し、下顎骨を露出、更に内測に於ては 顎舌骨筋定下顎骨より切霍しておく。ここで小曰歯或 は大曰歯を拻去し、Gnathotom を方けて下顎を切断

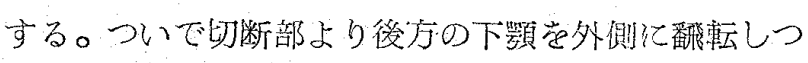
つ觔突起より側頭筋を切断すれば可動性が増すので、

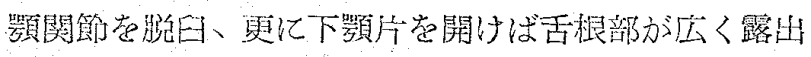

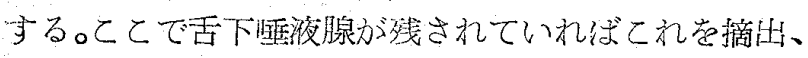

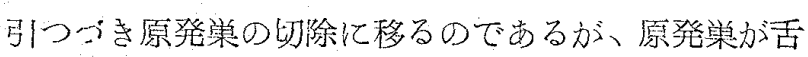
根部に近い場合々は㧢頭粘膜荧舌青上緣に向つて切開

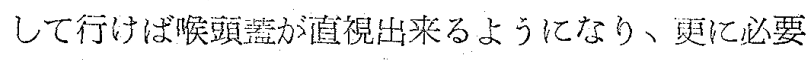

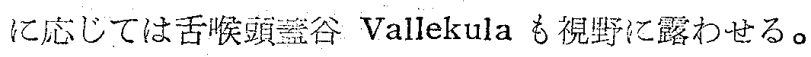

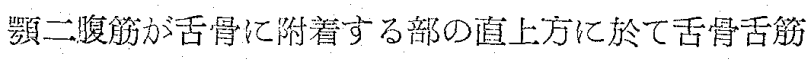
荧分けると舌動脈力涀出世るのでしれ結禁する。原

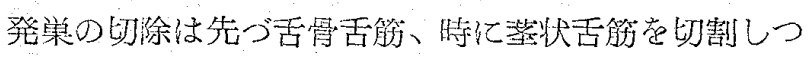
つ切俆予定の下方境界をつけて执いて、最後に舌春部

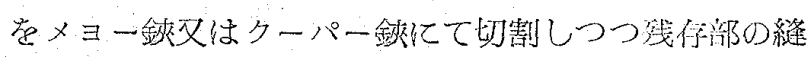

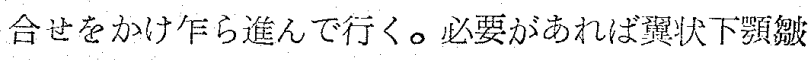

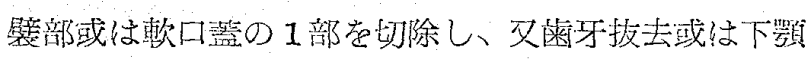

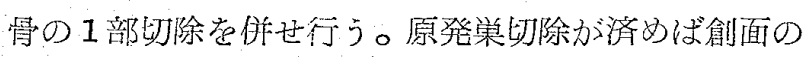

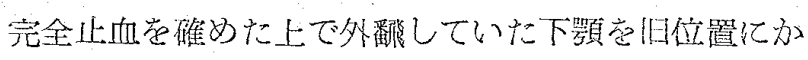
えし、下顎骨両断端の下縁近くにエンヂンとピーソー リーマーにて小玡孔䐴へ、銀線にて結染固定する。

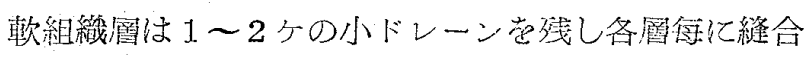
閉鎖する。

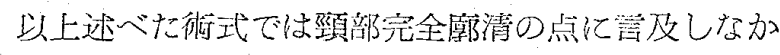
つたが、頸淋巴節転移の疑いあるもの或々予防的頙部

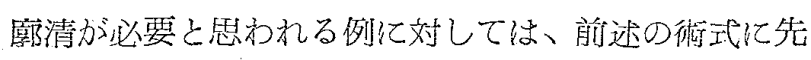
立つて俩鎖乳頭筫に沿つた切開によつて手街を始妨完 全頸部搱清 radical neckdissection 荧行い、引引づ

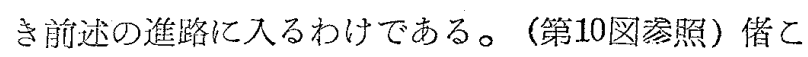

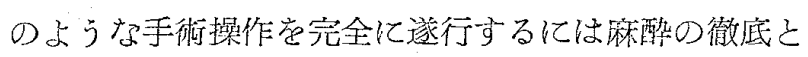
患者身体各系の管理が重要な役割を演ずるととは多言 苍要しない所である。局所麻酔によつても以上の操作

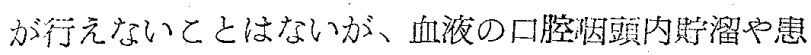

者の不安、舌操作中に於ける亢鹪等の影響によつて手 術不街坻に終り勝ちである。乙れ亿刘し本報告例に行 つた如く気管内雨管による閉鎖循環吸收式麻醉法によ れば以上の懸念は全く解決され、急者は身体各系管理 の下、安静、静萧裡に、術者は徹底した手術操作堂進 めるととが出来る。殊化本䇉告例中の第 2 例はプロカ インアレルギーを持つた患者であつて、プロカイン大 量使用は生命の绝険す方予想される例であつた方゙、閉 鎖循環式気管内麻醉儿よつてとの問題も併せ解決し得 たととは誠に言であつた。

\section{結 諭}

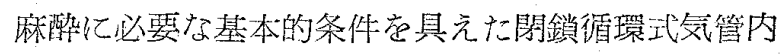
麻酰法す、乙れ袁顎外科分野に応用しようとすると、

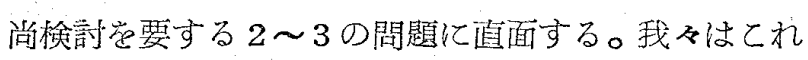
ら諸点の解決们つと少、本麻酔法の口腔外科手術への 店用分野を開拓しつつある。

尚最近注目されるに至つた混合尷断㓮 (Cocktail litique) の適量投与による所罚強化麻酷も亦口㬵外科 領域への応用価值が大である。

最近相次で遯遇した舌癌 2 症例の根治手術にあたつ

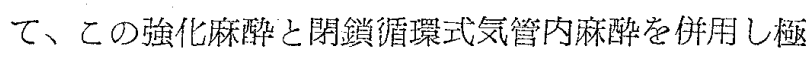
めて好成績觉得たので、その概要を報告し、例せて舌 癌根治手獄に対する著省等の見解を披濋した。

症例Iの池○例に於てはプロカインアレルギー学も つた费者であつて、従来の局所麻醉手術に上つては生 命の危険ず予測されたのであるが、本麻醉法の応用

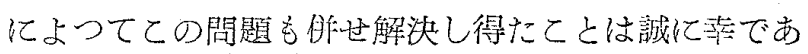
つた。

\section{交献}

1. Adriani, J.: Techniques and Procedures of Anesthesia, C. C. Thomas, 1954.

2. Norman, H. Olsen: J. A. D. A., VoL. 53, Nr 5, P. 548., 1956.

3. Murray, H. Hoffman: J. A. D. A., VoL. 53, Nr 5, P.554., 1956.

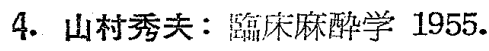

5. 恩地 裕：晽酷门反省 1955 .

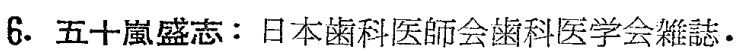
6 巻 42 号.

7. 佳々木之賢：麻酶 6 巻 1 号.

8. 原田 稔: 麻醉 6 巻 1 号.

9. 川上親世：蒾界展望 13 巻 11 号.

10. 後䏧敏郎: 手術 8 巻 12 号 1954 . 
11. 後藤敏郎：舌癌の手術 1955.

12. Schmieden, V.u.Fischer,A.W. : Der Chir urgische operations-kursus. 1930.
Chirurgische Operationslehre. Band I. 1920.

14. Kirschner, M.: Allgemeine u. spezielle chirurgische Operationslehre Bd 41956.

13. Bier, A., Braun, H. u. Kümmel, H. :

第 1 表

[症例．I]

[靑者名]下 $\bigcirc$ 虎 $\bigcirc 30 \mathrm{~J}$

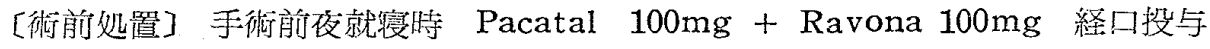

術前 2 時間 Pacatal $50 \mathrm{mg}$ 筋肉内注射

I時間

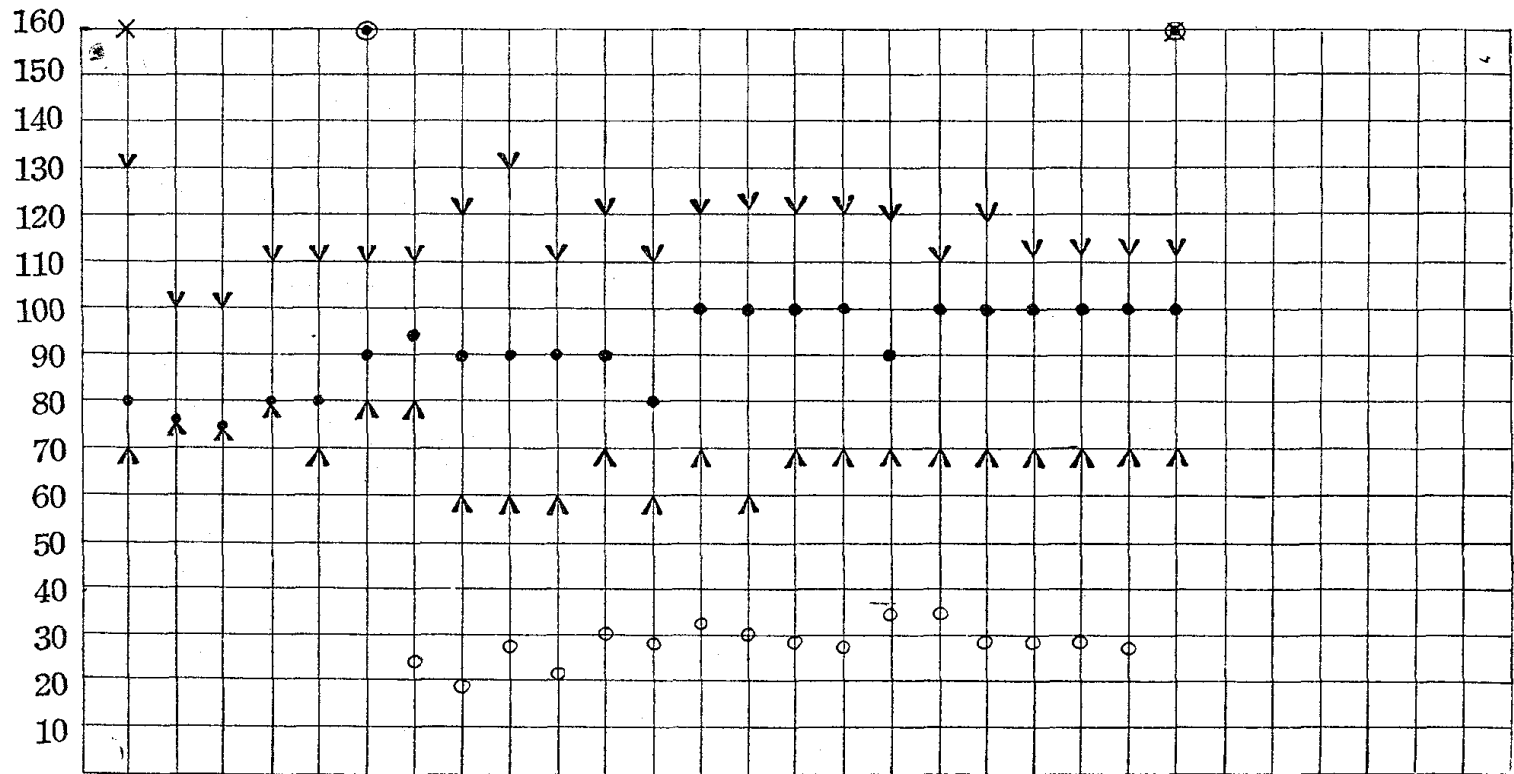

01020304050 T 1020304050 II 1020304050 III 1020304050 IV $1020304050 \quad \mathrm{~V}$ 亏五り $\uparrow \uparrow$

ボ\%ワェ插

ナ秠バ!管

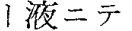

ル五ンル

裙○一酸

溥 $\mathrm{C}$ 糸

麻 C C吸

酶 $\mathrm{C}$ 入

\begin{tabular}{l} 
輸 \\
ffll \\
$=$ \\
\hline 至 \\
C \\
C
\end{tabular}

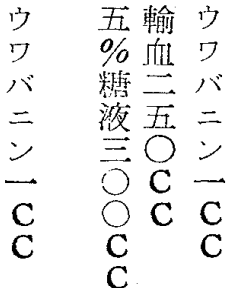

総 輸 血 量 $500 \mathrm{cc}$

総 婻 液 量 $800 \mathrm{cc}$

総 出 fil 量 $335 \mathrm{gr}$ 
[症例. II ]

第 2 表

[患者名]池 $\bigcirc$ 㦓 $\bigcirc 36 \mathbf{J}$ o

[術前処置] 手術前夜就葠時 Pacatal $100 \mathrm{mg}+$ Ravona $100 \mathrm{mg}$ 経口投与 術前 2 時間 Paoatal $50 \mathrm{mg}$ 筋肉内注射

工時間 " $50 \mathrm{mg}+$ Opystan $70 \mathrm{mg}$ 筋肉内注射

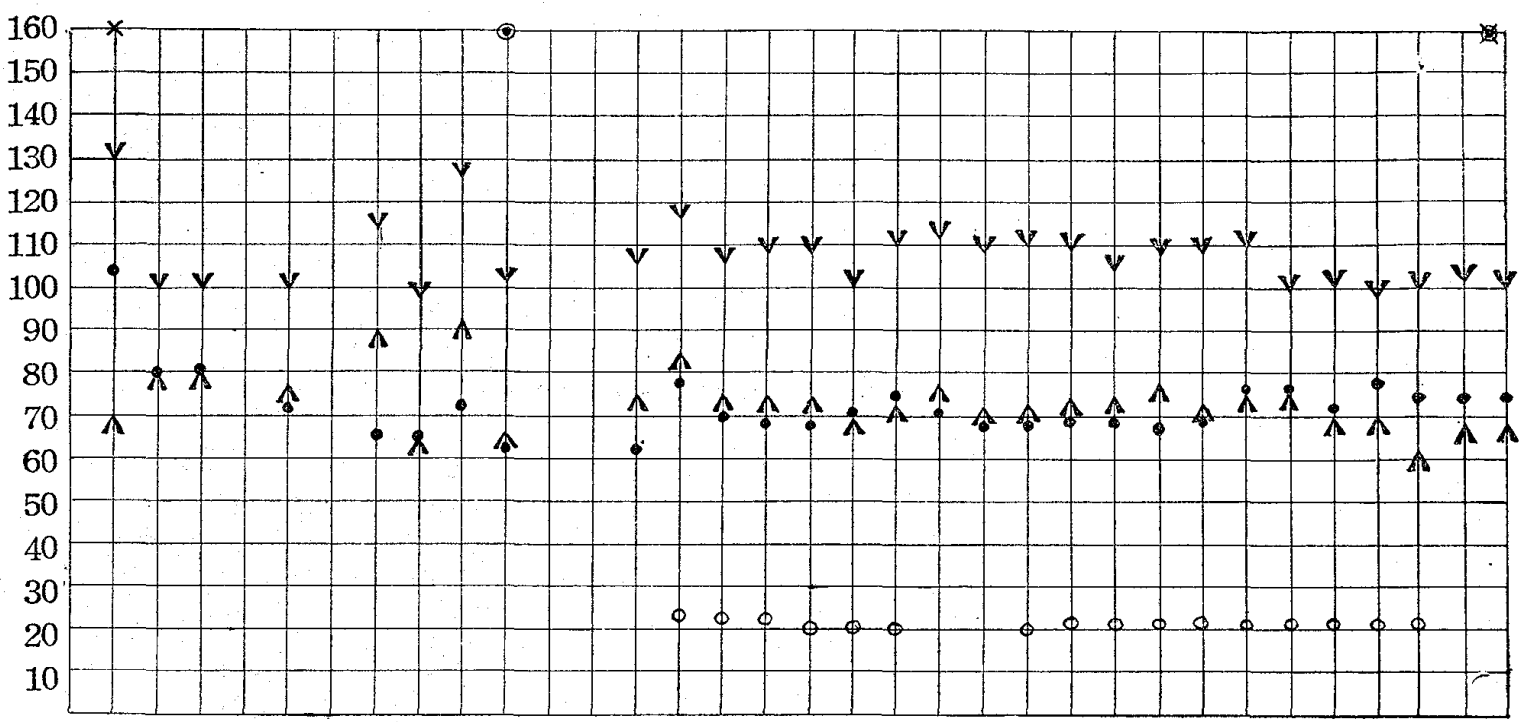

01020304050 I 1020304050 II 1020304050 II 1020304050 IV 1020304050 V 102030 亏酸五的 $\uparrow$ 的

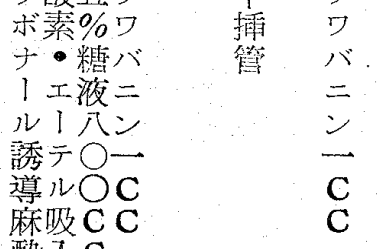

血 総輸 血量 $500 \mathrm{cc}$

吾.

総 輸液量 $800 \mathrm{cc}$

C 総出血量 $343 \mathrm{gr}$

酥入 $\mathrm{C}$ 
第 1 図

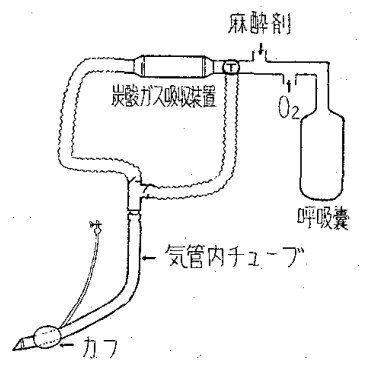

循環式回路模型図
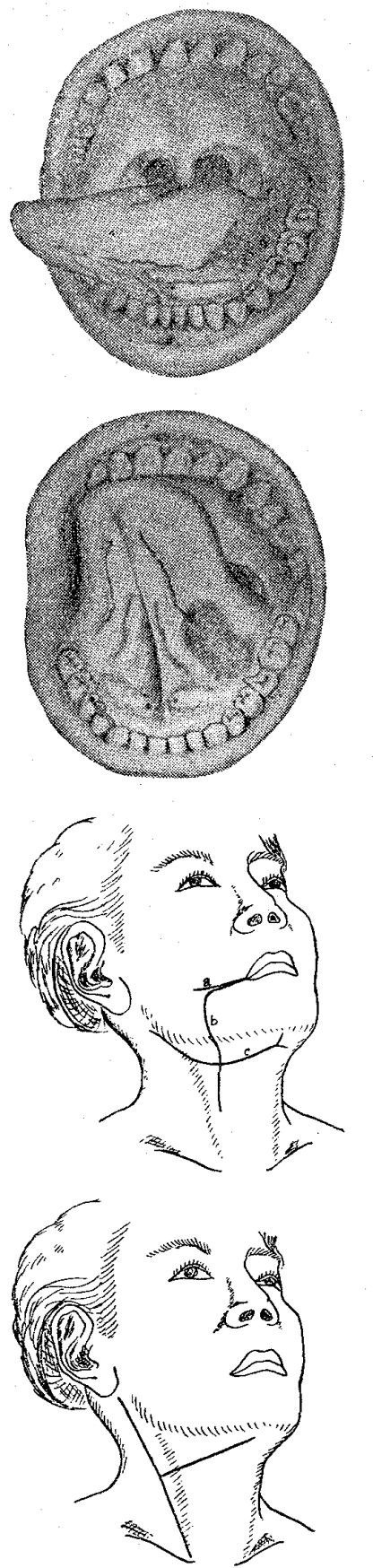

第2図（a）

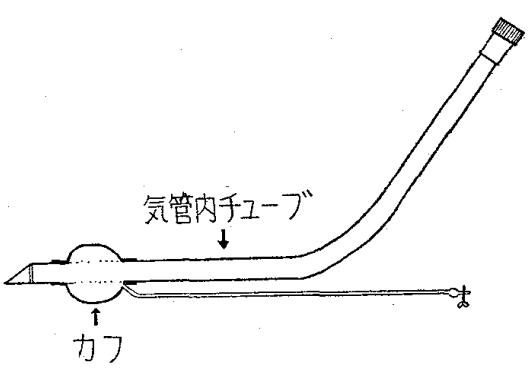

気管内チューブ
第2図 (b)

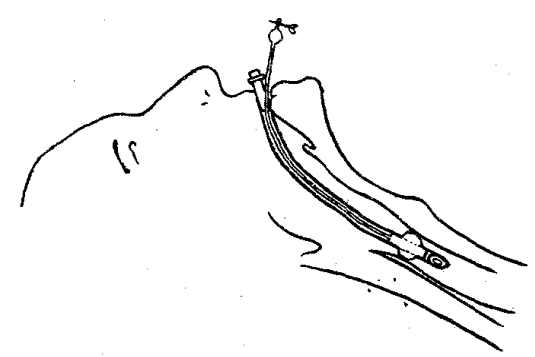

気管内捙管榀型図

\section{第3図}

症例1.下○例に於ける 原発㫦

\section{第5図}

症例2.池○例に打ける 原発沓

\section{第7図}

舌癌根治手術に於ける 切開線

a . 煩横切

b. Langenbeck 支切

c . 顎下部穹状切開 Kocher 攴切

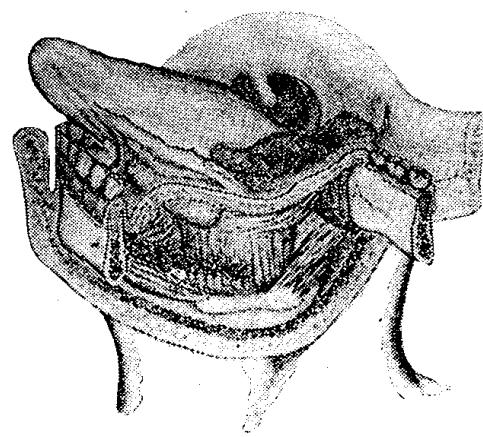

第 4図

症例1.下○例に於ける 手術々式定示す。

顎下睡液腺は覩に除去 され、顎下及び虍頁下部 范開搪、更江下顎を切 断して後方下䁚折党外

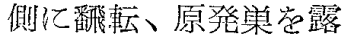
出した所。

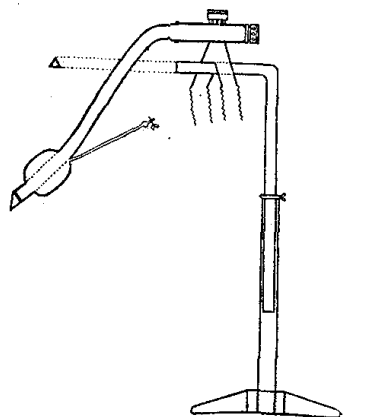

\section{第6図}

川上式固定台

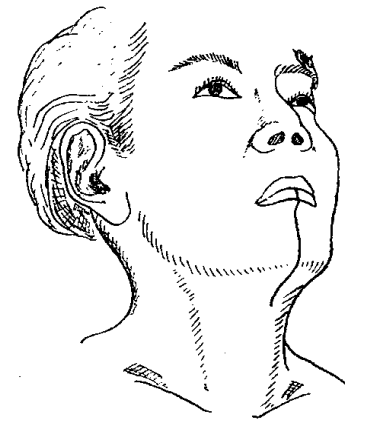

第8図

下顎中央鋸断化るる場 合の正中皮切

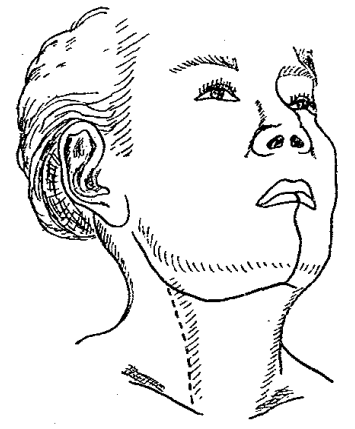

第10図

舌癌根治手術に於ける 平川度切 